DOI:10.24193/tras.2017.0001

Published First Online: 2017/02/10

\section{CAN (RE)CENTRALIZATION \\ BE A MODERN GOVERNANCE \\ IN RURAL AREAS?*}

\author{
István BALÁZS \\ István HOFFMAN
}

\section{István BALÁZS}

Professor, PhD, Department of Administrative Law, Faculty of Law, University of Debrecen, Debrecen, Hungary Senior research fellow, Institute of Legal Studies,

Centre for Social Studies, Hungarian Academy of Sciences, Budapest, Hungary

Tel.: 0036-52-512.700/ 77027

E-mail: balazs.istvan@law.unideb.hu

\section{István HOFFMAN}

Associate Professor, PhD, Department of Administrative Law, Faculty of Law, Eötvös Loránd University, Budapest, Hungary Tel.: 0036-14-116.519

E-mail: hoffman.istvan@ajk.elte.hu by the central budget in the 1990s and 2000s. The economic crisis resulted in a strong concentration trend in Hungary, as well. The new Hungarian Municipal Code introduced a Janus-faced model. The administration of the rural areas was strongly concentrated by the establishment of the mandatory common municipal offices of the small villages (under 2000 inhabitants) while the forms of the intercommunal associations were simplified. This reform reduced the number of local offices significantly. This type of intercommunal cooperation became the main form of the joined public service management as well, because the former significant state aid of the voluntary associations has been reduced.

Keywords: Hungary, local government, municipal reform, intercommunal cooperation, rural administration, public services, centralization, European comparison of municipal systems.
* This article was supported by the János Bolyai Research Scholarship of the Hungarian Academy of Sciences. 


\section{Introduction}

In Hungary, the system and the delivery of public services have changed radically in the last decade. The system was originally based on a strong, but fragmented municipal system, so the main goal of the reforms in the last decade was to strengthen this system and to solve the problem of economies of scale. The regulatory methods and the related budgetary support system applied for this aim will be examined in this article, especially in the field of rural areas governance.

We would like to examine - mainly based on the Hungarian reforms - the attempts to solve the economy of scale problem in a country which has a fragmented spatial structure. We would like to examine the Hungarian changes in the light of the transformation of the European rural governance, especially, the concentration of the municipal systems of the European countries.

The primary method of the research is jurisprudential, but the effects of the regulation and the practical outcome of the new support system will also be analyzed. Firstly, we would like to have a European overview, in which we would like to analyze the transformation of the rural governance in the European countries, and to analyze the trends of changes.

\section{The changes of the rural administration in Europe: a short international overview}

The structure of the European rural administration has changed in the last decades, too. This transformation had two periods.

\subsection{The first period of the transformation of the rural administration in Europe}

The first period can be classified as the 'classical' period of the concentration of local public services systems, which already began in the 1960s, but a significant part of these reforms was influenced by the New Public Management paradigm in the late 1980s and the 1990s. The Scandinavian model represented one type of the concentration, where the number of the municipalities was reduced radically in the 1960s. Thus in Denmark the number of the municipalities was 1,021 in 1967, and this number was reduced to 275 in 1975, and to 98 in 2008 (Blom-Hansen and Heeager, 2011, pp. 223224). Similar transformation has been occurred in Sweden, where the number of the local governments was 1,000 in 1967 and only 290 in 2008 (Lidström, 2011, pp. 270).

The Central European countries, especially West Germany chose another model of concentration. The number of (West) German municipalities was reduced, but not as radically as in the Nordic countries. An important element of the spatial reform of the German municipal system was the strengthening of the territorial level, accompanied by decreasing the number of regional entities (counties, the German Kreise) (Gern, 2015, pp. 150-151). Although a moderate merger of local and regional entities was executed, inter-municipal cooperation was promoted by the central and the provincial (Länder or in Switzerland the cantonal) governments. In these countries, several types of compulsory inter-municipal associations evolved (Neuhofer, 1998, pp. 558-560). 
The countries following the French (Napoleonic) model chose another type of reform. Several tasks and powers of the county councils were transferred to the new regional governments, thus the concentration process can be considered at the same time as a regionalization of the territorial administration. The local municipal system of these countries remained fragmented (see Table 1); inter-municipal cooperation was promoted by central governments. The intensity of this promotion was different in the given countries, it was used primarily by France after the loi Chevènement (1999), the act under which practically semi-compulsory inter-municipal associations were established (Hoffman, Fazekas and Rozsnyai, 2016, pp. 456-457).

Table 1: Numbers of the municipalities and their average population in 2005 in France, Italy, Spain and Greece

\begin{tabular}{l|c|c}
\hline \multirow{2}{*}{ Country } & \multicolumn{2}{c}{2005} \\
\cline { 2 - 3 } & $\begin{array}{c}\text { Number } \\
\text { of municipalities }\end{array}$ & $\begin{array}{c}\text { Average population } \\
\text { of the municipalities }\end{array}$ \\
\hline France & 36,559 & 1,600 \\
Italy & 8,104 & 7,000 \\
Spain & 8,082 & 4,800 \\
Greece & 5,922 & 1,800 \\
\hline
\end{tabular}

Source: Kovács (2013, p. 328)

\subsection{The second period of the transformation}

The second period of concentration began at the end of the 1990s. By this time, several dysfunctions of the NPM paradigm have been detected and new paradigms for example Good Governance and New Public Service - evolved (Pollitt and Bouckaert, 2011, pp. 11-19). Thus decentralization and privatization, formerly strengthened by the NPM, slowed down in Europe ${ }^{1}$. New tendencies emerged, but the economies of scale issue remained one of the major problems of the rural governance. Another line of transformation appeared after the 1960s and 1970s: the strong urbanization in Europe transformed the former logic of inter-municipality. Thus, the concept of urban government resulted in new inter-municipal entities in Europe.

The majority of the European countries did not intend to break up the decentralization process of the last decades, so they tried to solve the size inefficiencies within the municipal systems. Therefore, two major transformations have evolved: firstly, the inter-municipal cooperation had a 'renaissance' after the 1990s. This transformation is very spectacular in countries where this form of cooperation was poorly applied formerly. Thus, the significance of inter-municipality has been strengthened in the Nordic countries, whose former reforms were based on the merge of municipalities. For example, in Finland, social and health care systems are now based on in-

1 This change was considered by Tamás M. Horváth as a 'quiet revolution', which begun by the transformation of the tendering of public services and the public procurement procedures in Europe, especially by the new interpretation of the in-house public procurements and the new rules on the permissibility of the state aid (Horváth, 2013, pp. 175-178). 
ter-municipal cooperation: compulsory associations, 21 hospital districts and districts for social care were formed, which have been further merged under a new regulation from 2015. The merger of local governments is a quite important tool, as well.

The economic crisis accelerated concentration tendencies after 2008/2009, which also instigated tendencies of nationalization. The nationalization of the management of public services could already be observed after the Millennium - the first major nationalization was the Norwegian health care reform in 2002, by which the delivery and management of the inpatient health care became the task of the central government (Hagen and Vrangbæk, 2009, p. 114) - but its significance has heavily increased after the economic crisis. These reforms tried to solve the problems of size inefficiency outside the municipal system through the nationalization of public services to a strongly centralized structure. Another example for this type of reforms was the Estonian education reform in 2012. One of the main aims was to incentivize local governments to transfer the maintenance of upper-secondary schools to the central government (Auers, 2015, pp. 156-160). Nevertheless, probably the strongest nationalization took place in Hungary (see below, points 5-6) (Hoffman, Fazekas and Rozsnyai, 2016, pp. 458-459).

Even though nationalizations took place in several European countries, we can state that the major reforms mostly point to the concentration of municipalities. Thus, local governments preserved a significant part of their duties, while their economic role has moderately decreased in the majority of the Member States of the European Union (EU).

\section{The background: fragmented spatial structure in Hungary}

\subsection{Fragmented spatial structure in Hungary and the regulation bourgeois era}

Hungary has a fragmented spatial structure. The majority of the Hungarian municipalities had less than 1,000 inhabitants in 2010 (see Table 2).

Table 2: Population of the Hungarian municipalities (1990-2010)

\begin{tabular}{|c|c|c|c|c|c|c|c|c|c|c|}
\hline \multirow[t]{2}{*}{ Year } & $0-499$ & 500-999 & $\begin{array}{l}1,000- \\
1,999\end{array}$ & $\begin{array}{r}2,000- \\
4,999\end{array}$ & $\begin{array}{l}5,000- \\
9,999\end{array}$ & $\begin{array}{c}10,000- \\
19,999\end{array}$ & $\begin{array}{l}20,000- \\
49,999\end{array}$ & $\begin{array}{l}50,000- \\
99,999\end{array}$ & $100,000-$ & All \\
\hline & \multicolumn{10}{|c|}{ Inhabitants } \\
\hline 1990 & 965 & 709 & 646 & 479 & 130 & 80 & 40 & 12 & 9 & 3,070 \\
\hline 2000 & 1,033 & 688 & 657 & 483 & 138 & 76 & 39 & 12 & 9 & 3,135 \\
\hline 2010 & 1,086 & 672 & 635 & 482 & 133 & 83 & 41 & 11 & 9 & 3,152 \\
\hline
\end{tabular}

Source: Szigeti (2013, p. 282)

Therefore the governance of the rural areas in Hungary has been based on this condition, and the (inter-communal) cooperation has a significant role. Thus the communities of Hungary were classified into three groups by the first modern Municipal Code, the Act XVIII of 1871. The small villages belonged to the first group. These communities could not perform the tasks of a community independently, therefore they were obliged to form intercommunal cooperation, the so-called circles (kör). The 
large villages belonged to the second group. They could perform the tasks of a community independently. The small town (towns with regular council) belonged to the third group. They were under the control of the counties, but they had broader local governance. This classification remained the same practically until 1950. Thus the governance of the rural areas was based on the mandatory intercommunal cooperation of the (small) villages and the broad competences and tasks of the counties which were transmitted to the local areas by the leader of the districts (which were the agencies of the counties) by the chief constable (föszolgabíró) (Hoffman, 2009, pp. 88-92).

\subsection{The regulation of the Soviet-type administration}

After the World War II a Soviet administrative system evolved in Hungary. The administration of the rural system changed after 1950. In the first period the former intercommunal associations were liquidated. The district councils were established and several competences of the rural municipalities were transferred to these entities (Hoffman, 2009, pp. 105-109). This model changed after the reforms of 1968. The town areas (városkörnyék) were established by the Act I of 1971 on the Councils. From the 1960s a new tool of the rural governance appeared: the merger of the municipalities. The main form of this merging process was the formation of the common village councils (községi közös tanács). In this model the former municipalities preserved their formal independency, but their whole administrative structure was united, therefore a merged municipality was formed. Although merging communities was an important element of the new reforms, the intercommunal associations were reborn. The cooperation between towns and villages was not solved by the merge of the municipalities, and the town areas were not universal in the 1970s. Therefore the town-village associations - which can be classified as intercommunal cooperation (Kiss, 1985) - were established by a normative tool. Another important change was the elimination of the districts in 1983. By this reform the town areas became universal in the rural administration. This system existed until 1990. The former concentrated structure was converted by the evolvement of the new democratic Hungary.

\section{The starting point: the Act LXV of 1990 on the local self-governments}

In 1990 a new, local government system was established by the Amendment of the Constitution and by the Act LXV of 1990 on the Local Self-Governments (hereinafter: Ötv). This system was a two-tier, but local-level centered system. The first tier was the local (community) level. According to the Ötv villages, large villages, towns, county towns and Budapest as the capital city were considered as local-level governments (municipalities). The second tier was the county level. The county local governments had an intermediate service-provider role, but the county-level service delivery could largely be overtaken by the municipalities.

The local-centered nature of the Hungarian local government system was strength-

ened by the system of voluntary inter-municipal associations. Article 44/A of the amended (former) Constitution declared that the right to cooperate is a fundamental 
right of municipalities. These rights had similar constitutional protection as human rights, only at a lower level. Therefore, the introduction of a compulsory inter-municipal association system was very difficult (Verebélyi, 1999, pp. 30-36), almost impossible, due to the need for a broad political consensus.

Meanwhile, local public service systems - which were built on the duties and responsibilities of the local governments - had several dysfunctional elements. The main dysfunctional element was the fragmented spatial structure which was strengthened by democratic changes, as a counterpart to former Communist times: where compulsory inter-municipal associations (the above presented common village councils) treated size inefficiency problems. As we have mentioned, this type of inter-municipal cooperation was practically the merger of villages, as village councils and their administration were basically amalgamated. This compulsory form was unpopular among Hungarian municipalities; therefore, it disappeared with the democratic changes, giving opportunity to a disintegration tendency in the transition period (Hoffman, 2009, pp. 130-132).

This fragmentation and the related size inefficiency problem was tried to be solved by inter-municipal cooperation. The inter-municipal system of the Ötv was based on voluntary cooperation. The new types of associations could not stop the disintegration because of their purely voluntary nature and the poor financial support provided by the central budget. Therefore, the number of service provider associations was only 120 in 1992. The joined municipal administrations decreased in these years: the number of common municipal clerks was 529 in 1991, 499 in 1994, and only 260 administrative inter-municipal associations were established until 1994 (Hoffman, 2011, pp. 30-31). The lack of intercommunal cooperation, the fragmented spatial structure, and the weak, subsidiary intermediate level public service provider role of the county local governments resulted in significant service delivery dysfunctions. The local self-governments - especially the small villages which were the majority of the Hungarian municipalities - were not able to perform a significant part of the municipal tasks.

\section{The strengthening of inter-municipal associations}

\section{in the late 1990s and in the 2000s}

\subsection{Changes of the mid 1990s}

The dysfunctional phenomena of the new, democratic system became well recognizable already in 1992-1993. Therefore, in 1994 a partial review of the regulation took place. The reform left the paradigm of the voluntary inter-municipal cooperation unaltered, but introduced supplementary funding from the central budget for the establishment of inter-municipal associations and for their service delivery.

Another change was the clarification of the regulation on associations. Its rules were originally kept very scarce to secure a great organizational freedom for municipalities in this field, which resulted in a lacuna. Therefore, additional rules were ad- 
opted based on a French-type model, thus the institutional diversity of the various inter-municipal associations began to evolve after 1997. New, additional state subsidies were introduced to accelerate the formation of voluntary inter-municipal associations after 1997 (Balázs, 2014, p. 428). As a result of these changes, the number of inter-municipal associations radically increased after 1997 (see Table 3).

Table 3: Number of the inter-municipal associations responsible for public service provision between 1992 and 2005

\begin{tabular}{c|c}
\hline Year & $\begin{array}{c}\text { Number of the inter-municipal associations } \\
\text { responsible for public service provision }\end{array}$ \\
\hline 1992 & 120 \\
\cline { 2 - 2 } 1994 & 116 \\
1997 & 489 \\
1998 & 748 \\
1999 & 880 \\
2003 & 1,274 \\
2005 & 1,586 \\
\hline
\end{tabular}

Source: Belügyminisztérium (2005, p. 205)

The joined form of municipal administration was stimulated as well. The establishment of common municipal clerks was strongly supported by the central budget. Thus, the disintegration tendencies of the local administration stopped at the end of the 1990s, giving place to the concentration of the municipal administration in rural areas.

\subsection{Multi-purpose micro-regional inter-municipal associations after 2004}

In 2004, the legislator introduced a new type of inter-municipal association - the multi-purpose micro-regional association - based on the French inter-municipal association form 'SIVOM'. The central government significantly supported service delivery through associations: in 2004, the share of the special subsidies for them was $1.19 \%$ of the whole central government subsidies for local governments, and in 2011 it already reached 2.91\% (Hoffman, 2011, p. 31).

Experts agree that the multi-purpose micro-regional associations were modelled for the rural areas. The tasks which could be performed by these organizations were mainly the core services of the local municipalities. The micro-regional associations formed an umbrella, because the simpler association forms could be integrated into this type of cooperation. These simple associations remained, but their activities were coordinated by the micro-regions (Kovács, 2010, pp. 85-87).

Thus, a pure concentration tendency could be observed in the field of the Hungarian local public services from the late 1990s. The problems of size inefficiency and economies of scale were tackled within the municipal system by inter-municipal associations. As these types of intercommunal associations were modelled for rural areas, one of the greatest debts of concentration reforms around the Millennium was the lack of association forms for urban local governments (Horváth, 2015, pp. 48-49). 


\section{Changes after 2010: the age of recentralization}

The legal status of the Hungarian municipalities is determined by the new constitutional rules on the local self-governance. The former regulation was changed radically, the former decentralized model of the Ötv has been transformed by the new Constitution - the Fundamental Law of Hungary - and by the new Municipal Code - the Act CLXXXIX of 2011 on the Local Self-Governments of Hungary (hereinafter Mötv).

\subsection{Constitutional background}

Formerly the right to self-governance was institutionalized as a collective right by the Constitution, but the Fundamental Law defines the elements of the self-governance as competences. This model of the regulation was interpreted by the Constitutional Court of Hungary ${ }^{2}$. The Constitutional Court stated that the local governments have not fundamental rights, therefore they cannot sue constitutional complaint. Thus practically the legislation has a very broad competence to define the legal status of the local governments (Hoffman, 2015, pp. 3-8). The concept of the legislation on the local self-governments has been defined by this concept.

\subsection{The concept and the rules of the Mötv}

It was clear in the preparation phase of the new Municipal Code that the concept of the new legislation on local governments changed. After the change of system in 1989/1990, the legislation was based on the liberal democratic approach. The reforms in the 1990s and the 2000s was partly based on the New Public Management paradigm. The new system was a centralized one, which was based on the tools of the public law and public power. This approach was mirrored by the preamble of the Mötv where it states that the local governments are 'part of the state system', and their main task is to 'contribute the realization of the targets of the state defined by the Fundamental Law'.

These policy objectives have been implemented by the rules of the Mötv. Although the Mötv has similar rules on the right to local governance as the former Constitution, it is regulated in an Act of the Parliament thus the guarantees of the defense of this right are lower than earlier: this right is no more a constitutionally defined one. Although the Mötv contains a list of the main local government tasks, the local service performance role of the municipalities has been weakened, and the scope of the tasks has become narrower. Thus the legislator is allowed to reduce the local government tasks by the new regulation. Due to this remodeling, the concentration of the municipal local services has partially lost its significance. The regulation on voluntary tasks has been changed, as well. New criteria - mainly economic ones - have been defined and a stronger supervision has been introduced. Thus a simple model has

2 See: Resolution of the Constitutional Court of Hungary no. 3105 of 2014 (published on April 17 $7^{\text {th }}$ ) [3105/2014. (IV. 17.) AB végzés]. 
been chosen by the central government to reduce the fragmentation of the public service system: the most problematic service provisions were centralized and now they are performed by the local agencies of the central governments. The main tasks of the education, inpatient care, residential social care and residential child protection are performed by these agencies. The maintenance of the state-run schools belongs to the responsibilities of the Klebelsberg Maintainer Center which is a central agency with district and county level bodies. The residential social care and children protection institutes are maintained by the county agencies of the Directorate General of the Social and Children Protection. The inpatient health care institutions are maintained by the National Healthcare Service Center. Thus the local governments are mainly responsible for the settlement operation, for the maintenance of the kindergartens, for basic social care, for basic services of child protection, and for cultural services. Those settlement level municipalities which have more than 3,000 residents are primarily responsible for the maintenance of the infrastructure of the educational institutions (Fazekas et al., 2015, pp. 269-270). The transformation of the role of the central administration can be observed by the change of total expenditure of the budgetary chapter - practically the sectors - directed by the Ministry of Human (formerly National) Capacities (see Table 4).

Table 4: Total expenditures (in million HUF) of the budgetary chapter directed by the Ministry of Human Capacities ${ }^{3}$

\begin{tabular}{c|c}
\hline Year & $\begin{array}{c}\text { Total expenditures (in million HUF) of the budgetary chapter } \\
\text { directed by the Ministry of Human (formerly National) Resources }\end{array}$ \\
\cline { 1 - 2 } 2011 & $1,535,370.6$ \\
2012 & $1,949,650.5$ \\
2013 & $2,700,363.9$ \\
2014 & $2,895,624.8$ \\
2015 & $3,049,902.2$ \\
2016 & $3,011,947.7$ \\
\hline
\end{tabular}

Source: Act CLXIX of 2010 on the budget of the Republic of Hungary, Act CLXXXVIII of 2011, Act CCIV of 2012, Act CCXXX of 2013, Act C of 2014 and Act C of 2016 on the central budget of Hungary

Thus the local government tasks have been significantly reduced, which is reflected by the size of the local government expenditure: before the reforms, in 2010 the total local government expenditure was $12.8 \%$ of the GDP, while in 2016 it was $8.1 \%$ only (see Table 5).

Table 5: Local government total expenditure in Hungary (in \% of the GDP) 2002-2015

\begin{tabular}{c|c|c|c|c|c|c|c|c}
\hline Year & 2002 & 2006 & 2010 & 2011 & 2012 & 2013 & 2014 & 2015 \\
\hline $\begin{array}{c}\text { Local government total expenditure } \\
\text { (in \% of the GDP) }\end{array}$ & $12.9 \%$ & $13.0 \%$ & $12.8 \%$ & $11.6 \%$ & $9.4 \%$ & $7.6 \%$ & $7.9 \%$ & $8.1 \%$ \\
\hline
\end{tabular}

Source: Eurostat, 2016

3 Inflation rate was 3.9\% in 2011, 5.7\% in 2012, 1.7\% in 2013, and $-0.9 \%$ in 2014 based on the data of the Hungarian Central Statistical Office. 
Although the officers of the municipalities are responsible for a significant number of tasks delegated by the central government, the number of them is radically reduced by the establishment of the district offices (járási hivatalok) of the county government offices. Thus the former local-centered administrative system has been changed, as well. The local autonomy has not been harmed by these rules, and the formerly informal local political influence on the administrative decision has been reduced. But the centralization of administrative tasks caused dysfunctional phenomena several times.

The new municipal legislation tried to reduce the fragmentation of the spatial system by strengthening the towns which could now be responsible for the service provision for the settlements of their town area as well. Such a solution can be observed in the field of the cultural services: several institutions - formerly maintained by the counties (for example county museum and libraries) - were moved to the responsibility of county towns which perform the duty for the whole county (Hoffman, 2012a, pp. 166-167). Nevertheless, the legislator retained inter-municipal associations in a simplified form, with only one type of the inter-municipal association, which is a multi-purpose one with legal personality, managed by a council. Even though the former unincorporated forms should have been transformed, instead they just disappeared. Despite the simplification of the regulation, the differentiated task performance and the operation of diverse service delivery systems within the association are still allowed. Thus the new type of the association can be described as an umbrella organization, because the former independently organized associations - which did not have legal personality - could be mainly integrated into this new type of inter-municipal association (Nagy and Hoffman, 2014, pp. 309-312).

The freedom of formation of municipal bodies has been reduced by the institutionalization of the joined municipal administrations. As we have mentioned, the Fundamental Law allowed the legislator to establish compulsory inter-municipal associations by an Act (of Parliament). Thus, the Mötv established a new, compulsory form of the inter-municipal cooperation: the joint municipal office (Balázs, 2014, p. 426). Villages of the same district (járás) having less than 2,000 inhabitants are obliged to take part in these associations ${ }^{4}$. Villages having more than 2,000 inhabitants and towns can take part in such an association, if they become the headquarter municipality of these offices.

The greatest losers of the Hungarian municipal reforms were the county governments, because they lost their service provider role and a major part of their assets and revenues. From 2012 they were responsible for several coordinative tasks defined by the act of the Parliament (for example for county environment protection coordina-

4 There are only few exceptions: the common office could have less than 2,000 inhabitant, if at least 7 municipalities take part in the cooperation, or if the population is at least 1,500 inhabitant and the protection of the right of the (national) minorities requires the independent office. We would like to note that this - minority based exception - was modelled after the administration of three villages in county Vas, which have Slovenian majority. 
tion) and for several parts of the regional and rural development and planning (Hoffman, 2012b, pp. 29-31); however, the regional development agencies were managed by the central government until 2013. From 2014 a shared direction of these agencies may be established. Thus the county level became the agency of the central government primarily, because the county local government was weakened significantly.

The fiscal autonomy of the Hungarian municipalities has been weakened, as well. The earmarked and targeted central government subsidies, the modification of the local taxation reduced the economic freedom of the local governments.

We have mentioned several times that the reforms reduced the autonomy of the municipalities. Therefore, it has been a great question how much and what kind of municipal resistance have been indicated by these new rules. It is very interesting that just very limited resistance of the municipalities could be observed. It seems so, that it was more convenient for the municipalities that their debt were assumed by the central government than to fight for their competences (Pálné Kovács, 2013, pp. 27-29). The reforms have been modestly criticized by the international organizations, including the Council of Europe, as well. The first serious demonstration against the centralized public service system has evolved in 2015/2016: the centralized public education - and the dysfunctions of this system - has been criticized by broad groups of teachers, working unions, parents, and schoolboys and schoolgirls. Although the criticized phenomena are related to the centralization, the central elements of the disputes are not the organizational and administrative questions, but the pedagogical elements of these reforms. The decentralization of the system can be interpreted as an incidental claim.

\section{The impact of the reforms on regionalization, rural administration and intercommunal cooperation}

\subsection{End of the regionalization?}

As we have mentioned above the greatest losers of the reforms were the county governments. As the main impact of these reforms the county governments lost not only their territorial service provider role but practically they cannot be interpreted as public bodies with general powers. Although they formally had broad competences in the field of regional and rural development - thus it seems, the county governments are now 'developer counties' (Hoffman, 2014, pp. 411-412) - in fact only considerable funds are disposed by the counties. It should be remarked, that the regional development competences belonged to the counties before 2011, but they possessed only very limited development funds. Thus a very interesting situation can be observed, because the main competence of the counties are now these development tasks, which replaced the former public service performance.

The coordination tasks of the counties are not precisely defined by the Mötv. Although it could be interpreted as such a task which has a broad scope, and the counties can coordinate the activities of the local municipalities, but practically these tasks are powers which are regulated by several acts. 


\subsection{Inter-municipal associations in the new municipal system}

In the continental Europe, the intercommunal associations have a significant role in the rural development. As we have mentioned earlier, the mandatory associations were important tools of the Hungarian rural administration, especially in the bourgeois era, but the voluntary cooperation has had a weak tradition, and this form was not very popular among the Hungarian municipalities. Similarly, we have mentioned earlier, that two types of these voluntary associations could be classified as useful tools. These associations were voluntary, but the central government supported their establishment by additional funds. The first tool was the common municipal clerk of the villages which have - in principle - less than 1,000 inhabitants. The second one was the above presented micro-regional associations. It was reviewed by the Chapter IV of the intercommunal system that was changed by the Mötv. The formerly diversified system was simplified. Now just one type of the intercommunal associations can be formed which have legal personality and is governed by the council of the association. The new intercommunal associations get very limited support from the central government, in fact, the incentive grants have gone. The associations - which were based on the rules of the Ötv and the former act on intercommunal associations and cooperation (Act CXXXV of 1997) - should have transformed into the new association form defined by the Chapter IV of the Mötv in 2013. Because of the lack of the incentives and the centralized municipal tasks - practically the main tasks of the former associations were centralized, and these tasks are performed now by the central government and by its agencies - the number of the voluntary association seriously - by approx. $40 \%$ - dropped (see Table 6)

Table 6: Number of the (voluntary) intercommunal associations in 2013 and 2014

\begin{tabular}{ccc}
\hline Year & Number of (voluntary) intercommunal associations \\
\cline { 1 - 1 } 2013 & 1185 \\
\hline 2014 & 709 \\
\hline
\end{tabular}

Source: Országos Statisztikai Adatgyüjtési Program (2014)

\subsection{The trend of changes after 2012/13}

Thus the regionalization and the voluntary intercommunal cooperation is not preferred by the new Hungarian municipal system. The main cause of this phenomenon is that the central government tries to solve the problems of spatial fragmentation not by concentration of the local government system and by formation of bodies which have effective size, but by the centralization of the public services.

The concentration tendencies have been weakened by the Mötv in the field of local public services, and at the same time, the forms of joined municipal administrations have been strengthened. The Fundamental Law allowed the legislator to establish compulsory inter-municipal associations by an Act (of Parliament). As we have mentioned, the Mötv established a new, compulsory form of the inter-municipal cooperation: the joint municipal office. The result of this new regulation is a heavy concen- 
tration process: in 2014, the major form of local administration was already the joint municipal office (see Table 7).

Table 7: Municipal offices and joint municipal offices in Hungary (2014)

\begin{tabular}{|c|c|c|c|}
\hline \multicolumn{2}{|c|}{ Joint municipal offices } & \multirow{2}{*}{$\begin{array}{l}\text { Number of the (independent) } \\
\text { municipal offices } \\
\text { (mayor's offices) in Hungary }\end{array}$} & \multirow[b]{2}{*}{$\begin{array}{l}\text { Number of the local } \\
\text { municipalities in Hungary }\end{array}$} \\
\hline $\begin{array}{c}\text { Number of the joint } \\
\text { municipal offices }\end{array}$ & $\begin{array}{l}\text { Number of the participant } \\
\text { municipalities }\end{array}$ & & \\
\hline 749 & 2,632 & 521 & 3,153 \\
\hline
\end{tabular}

Source: Fazekas et al. (2014, p. 299)

If the villages do not freely contract for this joint municipal office, it is the commissioner of the government, who is empowered by the law to determine the villages taking part in the association and replace the agreement for its establishment. Of course, municipalities tried to fight this centralization process. Several municipalities, even though obliged, did not join the joint municipal offices. When the commissioner of government replaced their consent to the agreement and joined them forcedly to a joint municipal office, these municipalities sued these decisions before administrative courts. Several judges handling such cases turned to the Constitutional Court. The judicial applications accepted by the Court stated the regulation to be contrary to the European Charter of Local Governments. The Constitutional Court did not annul the contested rules; in its Resolution no. 22/2015 (published on June 15) it stated that the freedom of municipalities regarding the determination of their administrative structures has its limits in the provisions of the Fundamental law and other statutes setting up rules on these structures (Hoffman, Fazekas and Rozsnyai, 2016, pp. 465-466).

After the Resolution of the Constitutional Court only a corrective amendment bill was submitted to the Parliament, which has not been passed because the governing parties lost their two-third majority and the opposition did not support this act. Thus, there is practically no chance of global amendment of these regulations. The concept and approach on the local autonomy of the political decision-makers will not alter in short time, and there is not a strong request for the change of this concept among the experts and scientists. It seems to be that the changes are noted by the Hungarian decision-makers, local politicians, by the councils of the Hungarian municipalities and by the scientists and experts.

This situation has multiple causes. Some of them are not related to the Hungarian political situation. Thus the Hungarian (re)centralization fits into the European centralization and concentration trend after the global economic crises of 2008/2009. The adaptation of the local government system to the altered social, economic and administrative environment is a current challenge (Marcou, 2012), which tendencies were strengthened by the crisis. Although these changes can be observed in Europe, still there are some differences. The majority of the European countries try to solve these problems through changes in the municipal system. Although there are countries in which recentralization tendencies can be observed, Hungary centralized its public administration and its public service system very radically. 
One of the reasons for the lack of the resistance can be the request for these municipal reforms, even if the autonomy of the local self-governments is reduced strongly. There are other and new challenges, as well. Such a challenge of the last years is the migration crisis and the fight against terrorism which could be performed by the local entities only in a limited manner. The intervention into the local autonomy could be placed in a different light by these phenomena.

\section{Conclusions}

The Hungarian system based on the European Charter of Local Governments was one of the most decentralized municipal systems in Europe. Due to the fragmented spatial structure and broad responsibilities of the local governments, serious size inefficiency problems evolved in the rural governance, which were first tackled by a concentration tendency within the local government system, without the harm of the municipal autonomy. Voluntary inter-municipal associations were stimulated by financial aids and by the transformation of legal regulation. These reforms were consistent with the transformations in the European municipal systems where inter-municipality was one of the major tools of the rural governance.

The elements of the new model introduced in 2011 are not unknown in European democracies. It is rather the mixture of these elements, which is unfamiliar: a strong centralization of the delivery of former local public services, and at the same time the concentration of the local public administration. The former concentration of the local government system partially remained, but the inter-municipal associations are now mainly responsible for the joined local administrative tasks, which turns this form of concentration into a mode of centralization in its effects. Now, Hungary has a very centralized local administration system, in which the autonomy and the service provider role of the local governments (and their inter-municipal entities) have been largely weakened. The rural administration has been concentrated by the joined municipal offices, and several local powers and duties were centralized by the establishment of the district offices (járási hivatalok).

This transformation has been a much stronger centralization than the changes in the European countries after 2008/2009 where inter-municipality has remained a very significant tool.

\section{References:}

1. Auers, D., Comparative Politics and Government of the Baltic States. Estonia, Latvia and Lithuania in the 21 ${ }^{\text {st }}$ Century, Basingstoke, NY: Palgrave Macmillan, 2015.

2. Balázs, I., 'L'intercommunalité en Hongrie', in Steckel-Assouère, M.C. (ed.), Regards croisés sur les mutations de l'intercommunalité, Paris: L'Harmattan, 2014, pp. 425-435.

3. Belügyminisztérium, A helyi önkormányzati rendszer tizenöt éve. 1990-2005. 15 év a magyar demokrácia szolgálatában, Budapest: BM Duna Palota és Kiadó, 2005.

4. Blom-Hansen, J. and Heeager, A., 'Denmark: Between Local Democracy and Implementing Agency, in Loughlin, J., Hendriks, F. and Lidström, A. (eds.), Oxford Handbook 
of Local and Regional Democracy in Europe, Oxford: Oxford University Press, 2011, pp. 221-240.

5. Eurostat, 'Total Government Expenditures', 2016 [Online] available at http://epp.euro stat.ec.europa.eu/tgm/refreshTableAction.do;jsessionid=9ea7d07e30dcd247b519937c4 d909261df02fe3369b7.e34MbxeSahmMa40LbNiMbxaMchmTe0?tab=table\&plugin=1\& pcode=tec00023\&language=en, accessed on April 9, 2016.

6. Fazekas, J., Fazekas, M., Hoffman, I., Rozsnyai K. and Szalai, É., Közigazgatási jog. Álatalános rész I, Budapest: ELTE Eötvös Kiadó, 2015.

7. Gern, A., Deutsches Kommunalrecht, Baden-Baden: Nomos, 2015.

8. Hagen, T.P. and Vrangbæk, K., 'The Changing Political Governance Structure of Nordic Health Care Systems', in Magnussen, J., Vrangbæk, K. and Saltman, R.B. (eds.), Nordic Health Care Systems. Recent Reforms and Current Policy Challenges, Maidenhead: Open University Press, 2009, pp. 107-125.

9. Hoffman, I., Önkormányzati közszolgáltatások szervezése és igazgatása, Budapest: ELTE Eötvös Kiadó, 2009.

10. Hoffman, I., 'A helyi önkormányzatok társulási rendszerének főbb vonásai', 2011, Új Magyar Közigazgatás, vol. 4, no. 1, pp. 24-34.

11. Hoffman, I., 'Differenciált hatáskör-telepítés és városkörnyékiség a helyi-területi igazgatás rendszerében', 2012a, Jogtudományi Közlöny, vol. 67, no. 4, pp. 157-168.

12. Hoffman, I., 'Modellváltás a megyei önkormányzatok feladat- és hatásköreinek meghatározásában: generálklauzula helyett enumeráció?', 2012b, Közjogi Szemle, vol. 5, no. 2, pp. 26-34.

13. Hoffman, I., 'The Changes of the Roles of Hungarian Counties: Towards a One and a Half-Tier System?', 2014, Lex localis - Journal of Local Self-Government, vol. 12, no. 3, pp. 393-416.

14. Hoffman, I., 'Az Alkotmánybíróság döntése a „lex Margitsziget' alaptörvény-ellenességéről szóló alkotmányjogi panaszról. Az önkormányzatok feladat- és hatásköre védelmének alkotmányos keretei', 2015, Jogesetek Magyarázata, vol. 6, no. 1, pp. 3-8.

15. Hoffman, I., Fazekas, J. and Rozsnyai, K., 'Concentrating or Centralising Public Services? The Changing Roles of the Hungarian Inter-municipal Associations in the Last Decades', 2016, Lex localis - Journal of Local Self-Governments, vol. 14, no. 3, pp. 453-473.

16. Horváth, M.T., Magasfeszültség. Városi szolgáltatások, Budapest and Pécs: Dialóg-Campus, 2015.

17. Kiss, L., 'Az igazgatási társulások helye, szerepe és fejlesztésük irányai Baranya megyében', in Ádám, A. and Farkas, K. (eds.), Államigazgatás, terület- és településpolitika (Tanulmányok Baranya megyéből), Pécs: JPTE, 1985, pp. 147-161.

18. Kovács, K., 'Vidéki változások a rendszerváltás után', in Barta, Gy., Beluszki, P., Földi, Zs., Kovács K. (eds.), A területi kutatások csomópontjai, Pécs: MTA RKK, 2010, pp. 73-104.

19. Kovács, R., 'A helyi önkormányzatok jellemző adatai nemzetközi összehasonlításban, táblázatok', in Horváth, M.T. (ed.), Kilengések. Közszolgáltatási változások, Budapest Pécs: Dialóg Campus, 2013, pp. 325-348.

20. Lidström, A., 'Sweden: Party-dominated Subnational Democracy under Challenge?', in Loughlin, J., Hendriks, F. and Lidström, A., Oxford Handbook of Local and Regional Democracy in Europe, Oxford: Oxford University Press, 2011, pp. 261-281. 
21. Marcou, G., 'La reforme des collectivités territoriales en Europe', 2012, Revue Francaise d'Administration Publique, vol. 141, pp. 183-205.

22. Nagy, M. and Hoffman, I. (eds.), A Magyarország helyi önkormányzatairól szóló törvény magyarázata, Budapest: HVG-Orac, 2014.

23. Neuhofer, H., Gemeinderecht, New York: Springer, 1998.

24. Országos Statisztikai Adatgyüjtési Program - National Statistical Research Program No. 1621) - társulások (inter-communal associations) 2014. II. félév (2014 Q3-Q4), [Online] available at https://www.ksh.hu/docs/hun/info/adatgyujtes/2014/4_melleklet_ KIM.pdf, accessed on April 10, 2016.

25. Pálné Kovács, I., ‘Miért hagytuk, hogy így legyen? A területi decentralizációs reformok természetrajza Magyarországon', 2013, Politikatudományi Szemle, vol. 22, no. 4, pp. 7-34.

26. Pollitt, C. and Bouckaert, G., Public Management Reform, $3^{\text {rd }}$ edition, Oxford: Oxford University Press, 2011.

27. Szigeti, E., 'A közigazgatás területi változásai', in Horváth, M.T., Kilengések. Közszolgáltatási változások, Budapest-Pécs: Dialóg Campus, 2013, pp. 267-287.

28. Verebélyi, I. (ed.), Az önkormányzati rendszer magyarázata, Budapest: KJK-Kerszöv, 1999.

29. Hungarian Central Statistical Office, [Online] available at www.ksh.hu, accessed on April 5, 2016.

30. Act LXV of 1990 on the Local Self-Governments, published in the Hungarian Gazette Official Journal of Hungary, August 14, 1990.

31. Act CXXXV of 1997 on intercommunal associations and cooperation, published in the Hungarian Gazette - Official Journal of Hungary, December 15, 1997.

32. Act CLXXXIX of 2011 on the Local Self-Governments of Hungary, published in the Hungarian Gazette - Official Journal of Hungary, December 28, 2011.

33. Act CLXIX of 2010 on the budget of the Republic of Hungary, published in the Hungarian Gazette - Official Journal of Hungary, December 30, 2010.

34. Act CLXXXVIII of 2011 on the central budget of Hungary in the year 2012, published in the Hungarian Gazette - Official Journal of Hungary, December 28, 2011.

35. Act CCIV of 2012 on the central budget of Hungary in the year 2013, published in the Hungarian Gazette - Official Journal of Hungary, December 18, 2012.

36. Act CCXXX of 2013 on the central budget of Hungary in the year 2014, published in the Hungarian Gazette - Official Journal of Hungary, December 22, 2013.

37. Act C of 2014 on the central budget of Hungary in the year 2015, published in the Hungarian Gazette - Official Journal of Hungary, December 29, 2014.

38. Act $C$ of 2015 on the central budget of Hungary in the year 2016, published in the Hungarian Gazette - Official Journal of Hungary, July 4, 2015. 